\title{
PROFIL ASAM AMINO DAN NUTRIEN LIMBAH BIJI DURIAN (Durio zibethinus Murr) YANG DIFERMENTASI DENGAN RAGI TAPE (Saccharomyces cerevisiae) DAN RAGI TEMPE (Rhizopus oligosporus)
}

\author{
Lezita Malianti ${ }^{1)},{ }^{2}$ Endang Sulistiyowati ${ }^{2)}$, Yosi Fenita ${ }^{2)}$ \\ ${ }^{1)}$ Program Pascasarjana Pengelolaan Sumber Daya Alam dan Lingkungan, Fakultas \\ Pertanian, Universitas Bengkulu \\ ${ }^{1)}$ Mahasiswa Program Pascasarjana Pengelolaan Sumberdaya Alam UNIB \\ ${ }^{2)}$ Jurusan Peternakan Fakultas Pertanian Universitas Bengkulu
}

\begin{abstract}
ABSTRAK
Pemanfaatan limbah yang belum mempunyai nilai ekonomis, berlimpah dan mengandung gizi relatif baik bahkan dapat mengurangi pencemaran lingkungan adalah tindakan bijaksana. Biji durian adalah salah satu limbah yang cenderung meresahkan masyarakat disaat musim buah durian. Namun pemanfaatannya sebagai sumber pakan masih sangat terbatas. Hal ini disebabkan rendahnya kualitas gizi biji durian merupakan faktor pembatas dalam pemanfaatanya sebagai pakan ternak. biji durian harus diolah terlebih dahulu agar nilai gizinya meningkat. Penelitian ini bertujuan untuk mengetahui pengaruh fermentasi dengan beberapa level Saccharomyces cerevisiae dan Rhizopus oligosporus terhadap peningkatan kualitas nutrisi tepung biji durian. Penelitian ini dilaksanakan pada Bulan Februari-November 2018 di Desa Sri Kuncoro Kabupaten Bengkulu Tengah, analisa Proksimat dilakukan di Laboratorium Nutrisi dan Bahan Makanan Ternak Universitas Bengkulu serta analisa Asam Amino dilakukan Laboratorium Terpadu Institut Pertanian Bogor. Rancangan percobaan yang digunakan adalah Rancangan Acak Lengkap (RAL) dengan 5 perlakuan dan 4 ulangan. Steel dan Torrie (1991), dengan perlakuan yang diujikan sebagai berikut : F0 (kontrol) = Tepung Biji Durian Kukus; FS 0,5 = Fermentasi dengan 0,5\% Saccharomyces cerevisiae; FS $0,75=$ Fermentasi dengan $0,75 \%$ Saccharomyces cerevisiae; FR 0,5 = Fermentasi dengan 0,5\% Rhizopus oligosporus; FR 0,75 = Fermentasi dengan 0,75\% Rhizopus oligosporus. parameter yang diamati adalah asam amino, protein kasar, kadar air, bahan kering, bahan organik, serat kasar, lemak kasar dan abu tepung biji durian yang difermentasi dengan Saccharomyces cerevisiae dan Rhizopus oligosporus pada lama penyimpanan 48 jam. Hasil penelitian menunjukkan bahwa perlakuan fermentasi tepung limbah biji durian dengan ragi tape (Saccharomyces cerevisiae) dan ragi tempe (Rhizopus oligosporus) tidak meningkatkan kandungan asam amino dan nutrisi hanya terjadi penurunan pada nilai serat kasar. Hasil terbaik yang menunjukkan perubahan nilai nutrisi yaitu pada perlakuan dengan menggunakan ragi tape $0,75 \%$ mengacu pada kemampuan menguraikan serat kasar.
\end{abstract}

Kata Kunci : : limbah biji durian, fermentasi, saccharomyces cerevisiae, rhizopus oligosporus, asam amino

\section{PENDAHULUAN}

Biji durian adalah salah satu limbah yang cenderung meresahkan masyarakat disaat musim buah durian. Pemanfaatan limbah yang belum mempunyai nilai ekonomis, berlimpah dan mengandung gizi relatif baik bahkan dapat mengurangi pencemaran lingkungan adalah tindakan bijaksana. Selama ini biji durian belum begitu termanfaatkan dan dibuang begitu saja sebagai sampah limbah yang pada akhirnya dapat menimbulkan aroma yang tidak sedap, bahkan menggunung mengganggu kebersihan dan keindahan lingkungan. 
Berdasarkan Laporan Hasil Badan Pusat Statistik Provinsi Bengkulu (2013), produksi durian Bengkulu berkisar 174.882 ton pertahun. Satu buah durian mempunyai berat rata-rata $3 \mathrm{~kg}$, dengan demikian dapat diasumsikan bahwa setiap tahunnya dapat dihasilkan 58.294.000 buah durian. Tiap satu buah durian berisi lebih kurang 25 buah biji durian sehingga setiap tahunnya dihasilkan limbah biji durian 1.457.350.000. Dalam pembuatan satu kilogram tepung biji durian dibutuhkan biji durian sebanyak 100 buah, sehingga dapat diasumsikan bahwa setiap tahunnya Provinsi Bengkulu menghasilkan sekitar $14.573,5$ ton tepung biji durian.

Biji durian juga dapat dijadikan sumber pakan bagi ternak unggas karena kandungan nutrisi yang baik khususnya karbohidrat dan protein. Berdasarkan hasil analisa proksimat di Laboratorium Balai Penelitian Pascapanen Pertanian Bogor (2013), tepung biji durian yang dikukus selama 15 menit mempunyai kandungan lemak 0,25 persen, protein 8,61 persen, serat kasar 4,13 persen, abu 3,17 persen, BETN 70,21 persen dan energi metabolis sebesar $3493 \mathrm{kkal} / \mathrm{kg}$.

Namun pemanfaatannya sebagai sumber pakan masih sangat terbatas. Hal ini disebabkan rendahnya kualitas gizi biji durian. Tingginya kandungan $\mathrm{HCn}$ (Asam Sianida) merupakan faktor pembatas dalam pemanfaatanya sebagai pakan ternak. biji durian harus diolah terlebih dahulu agar nilai gizinya meningkat. Beberapa metode pengolahan fisik yang telah diujikan dan terbukti mampu meningkatkan nilai gizi dan menurunkan kandungan $\mathrm{HCn}$ limbah biji durian (Rita et al., 2014).

Menurut (Winarno et al., 2004) Fermentasi limbah bahan mulai sering dilakukan akhir-akhir ini, karena selain lebih mudah dan murah juga lebih aman dan lebih ramah lingkungan dibanding dengan penggunaan bahan kimia, Bahan yang mengalami fermentasi biasanya mempunyai nilai gizi yang lebih baik dari asalnya, disebabkan oleh mikroorganisme yang memecah komponen-komponen komplek menjadi zat-zat yang sederhana sehingga mudah dicerna. Sasongko (2009) juga mengatakan bahwa proses fermentasi dapat menurunkan kadar senyawa toksik seperti asam sianida, asam oksalat dan asam fitat.

$$
\text { Ragi tape (Saccharomyces }
$$
cerevisiae) dan Ragi tempe (Rhizopus oligosporus) telah banyak dimanfaatkan untuk meningkatkan produksi ternak unggas, namun tetap harus diperhatikan level penggunaannya karena pada beberapa kasus diantaranya Saccharomyces cerevisiae dapat menimbulkan penyakit "saccharomikosis" yang terjadi akibat populasi Saccharomyces cerevisiae melebihi populasi mikroba lain yang menyebabkan terganggunya keseimbangan mikroflora dalam tubuh.

Dari uraian di atas maka dilakukan penelitian untuk mengetahui pengaruh kapang jenis Saccharomyces cerevisiae dari ragi tape dan Rhizopus oligosporus dari ragi tempe yang digunakan untuk fermentasi biji durian.

Tujuan penelitian ini mengetahui pengaruh fermentasi dengan beberapa level Saccharomyces cerevisiae dan Rhizopus oligosporus terhadap peningkatan kualitas nutrisi tepung biji durian.

\section{METODE PENELITIAN}

\section{Waktu dan Tempat Penelitian}

Penelitian ini dilaksanakan pada Bulan Februari-November 2018 di Desa Sri Kuncoro Kabupaten Bengkulu Tengah, analisis Proksimat dilakukan di Laboratorium Nutrisi dan Bahan Makanan Ternak Universitas Bengkulu serta analisa Asam Amino dilakukan Laboratorium Terpadu Institut Pertanian Bogor.

\section{Alat dan Bahan}

Materi yang digunakan dalam penelitian ini yaitu tepung biji durian kukus, Saccharomyces cerevisiae (ragi tape), Rhizopus oligosporus (ragi tempe) yang didapatkan di pasar tradisional dan aquades. 
Sedangkan alat yang digunakan yaitu alat pengukus, timbangan analitik digital, sendok pengaduk, plastik, blender, ayakan dan alat-alat laboratorium untuk analisis.

\section{Perlakuan}

Rancangan percobaan yang digunakan adalah Rancangan Acak Lengkap (RAL) dengan 5 perlakuan dan 4 ulangan. Steel dan Torrie (1991), dengan perlakuan yang diujikan sebagai berikut :

F0 (kontrol) $=$ Tepung Biji Durian Kukus (TBDK), FS $0,5=$ TBDK Fermentasi dengan 0,5\% Saccharomyces cerevisiae, FS $0,75=$ TBDK Fermentasi dengan 0,75 $\%$ Saccharomyces cerevisiae, FR 0,5= TBDK Fermentasi dengan 0,5\% Rhizopus oligosporus, FR 0,75 = TBDK Fermentasi dengan $0,75 \%$ Rhizopus oligosporus

\section{Pembuatan Tepung Biji Durian Fermentasi}

Limbah biji durian yang digunakan dalam penelitian ini difermentasi dengan ragi tape (Saccharomyces cerevisiae) dan ragi tempe (Rhizopus oligosporus). Prosedur fermentasi dilakukan berdasarkan petunjuk Ciptadi dan Nasution (1980), tahap pertama fermentasi ini adalah dengan cara mengukus tepung biji durian menggunakan panci pengukus sederhana selama 30 menit. Selanjutnya biji durian yang sudah dikukus didinginkan sampai mencapai suhu kamar. Inokulasi dilakukan dengan mencampurkan $0,5 \%$ dan $0,75 \%$ masing-masing jenis ragi dari berat biji durian sesuai perlakuan, diaduk hingga merata. Biji durian yang telah diinokulasi dengan ragi dimasukkan ke dalam kantong plastik dan ditutup rapat kemudian ditutup dengan kain tipis dan didiamkan selama 48 jam, pada tahap akhir fermentasi biji durian dikeringkan dengan cara menjemur dibawah sinar matahari. Selanjutnya tepung biji durian yang telah kering dianalisa di laboratorium untuk mengetahui kandungan asam amino dan nutrien dari masing-masing perlakuan.

\section{Parameter yang Diamati}

Biji durian yang sudah difermentasi Saccharomices cerevisiae dan Rhizopus oligosporus diukur kadar asam amino, protein kasar, kadar air, bahan kering, bahan organik, serat kasar, lemak kasar dan abu . Analisis kandungan protein menggunakan metode Kjeldahl dan analisis asam- amino menggunakan HPLC (Ariffin et al., 2014).

\section{Analisis Data}

Data yang diperoleh dianalisis variansnya (ANOVA) menurut Steel and Torrie (1991) dengan diuji F untuk mengetahui pengaruh perlakuan. Jika ada pengaruh perlakuan yang signifikan dilanjut dengan uji DMRT (Duncan's Multiple Range Test) dengan menggunakan software SPSS (Statistical Package for the Social Sciences) Versi 22.

\section{HASIL DAN PEMBAHASAN}

\section{Proksimat}

Rataan nilai analisis proksimat berupa kadar air (KA), berat kering (BK), protein kasar (PK), serat kasar (SK), lemak kasar (LK) dan Abu dari sampel 5 perlakuan tepung biji durian sebelum dan setelah fermentasi dengan menggunakan ragi tape dan ragi tempe pada level yang berbeda, dapat dilihat pada Tabel 1 berikut.

Tabel 1. Rataan kandungan nutrisi tepung biji durian fermentasi

\begin{tabular}{|c|c|c|c|c|c|c|}
\hline \multirow[t]{2}{*}{ Variabel } & F0 & FS0,5 & $\mathrm{FS} 0,75$ & FR0,5 & FR0,75 & Notasi \\
\hline & \multicolumn{4}{|c|}{$\%$} & & \\
\hline Kadar Air (\%) & $6,73 \pm 0,42^{\mathrm{a}}$ & $5,81 \pm 1,33^{\text {a }}$ & $14,71 \pm 3,21^{\mathrm{b}}$ & $5,66 \pm 0,97^{\mathrm{a}}$ & $12,23 \pm 2,70^{\mathrm{b}}$ & $* *$ \\
\hline Berat Kering (\%) & $93,28 \pm 0,42$ & $84,09 \pm 11,94$ & $81,86 \pm 6,03$ & $86,26 \pm 9,61$ & $87.77 \pm 2,70$ & $\mathrm{~ns}$ \\
\hline Protein Kasar $(\%)$ & $6,75 \pm 0,20$ & $6,95 \pm 0,63$ & $5,99 \pm 0,13$ & $6,33 \pm 0,35$ & $6.47 \pm 0,49$ & ns \\
\hline Serat Kasar (\%) & $2,60 \pm 0,59$ & $2,68 \pm 0,51$ & $1,27 \pm 0,23$ & $2,96 \pm 2,21$ & $3,26 \pm 1,60$ & $\mathrm{~ns}$ \\
\hline Lemak Kasar (\%) & $0,82 \pm 0,13$ & $0,67 \pm 0,20$ & $0,61 \pm 0,18$ & $0.40 \pm 0,31$ & $0,63 \pm 0,22$ & ns \\
\hline $\mathrm{Abu}(\%)$ & $4,62 \pm 0,24$ & $5,73 \pm 2,74$ & $4,05 \pm 0,13$ & $4,27 \pm 0,19$ & $3,90 \pm 0,32$ & ns \\
\hline
\end{tabular}


Keterangan : Superskrip yang diikuti dengan huruf kecil yang bebeda pada kolom yang sama menunjukkan perbedaan yang sangat nyata $(\mathrm{P}<0,01)$ antar perlakuan.

Kadar Air

Berdasarkan hasil sidik ragam menunjukkan bahwa fermentasi tepung limbah biji durian dengan menggunakan Saccharomyces cerevisiae dan Rhizopus oligosporus berpengaruh sangat nyata $(\mathrm{P}<0,05)$ terhadap peningkatan kadar air tepung biji durian fermentasi. Hasil penelitian menunjukkan bahwa pada tepung biji durian sebelum fermentasi sebesar $6,73 \%$. Terjadi peningkatan yang signifikan pada kadar air perlakuan fermentasi dengan Saccharomyces cerevisiae dan Rhizopus oligosporus pada masing-masing perlakuan.

Perbedaan Kadar air sebelum dan sesudah proses fermentasi disebabkan karena adanya aktivitas pada saat proses fermentasi berlangsung yang dapat meningkatkan kadar air bahan. Kadar air bahan setelah fermentasi bisa lebih tinggi dibandingkan sebelum atau tanpa fermentasi, proses fermentasi yang menghasilkan air metabolisme merupakan indikator keberlangsungan proses fermentasi. Semakin tinggi peningkatan kadar air yang terjadi, semakin efektif proses fermentasi berlangsung.

Penelitian ini menunjukkan bahwa terdapat perbedaan peningkatan kadar air dengan adanya perbedaan komposisi bahan yang dikandung pada setiap perlakuan. Peningkatan kadar air terjadi pada perlakuan FS0,75 dan FR0,75 yaitu memperoleh hasil $14,7 \% 1$ dan $12,23 \%$, dan nyata lebih $(\mathrm{P}<0,05)$ tinggi dibandingkan dengan perlakuan F0, FS0,5 dan FR0,5 yang memiliki kadar air sebesar 6,72\%, 5,81\% dan $5,66 \%$. Hal ini mengindikasikan proses fermentasi yang berlangsung efektif terhadap tepung limbah biji durian, terjadi peningkatan kadar air pada perlakuan FS0,75 dan FR0,75 menunjukkan bahwa fermentasi menurunkan kualitas mutu bahan dikarenakan bahan pakan dengan kadar air yang tinggi memiliki daya simpan yang relatif pendek. Menurut Richana et al., (2010), tepung terigu yang memiliki kadar air 13 sampai $15 \%$ memiliki masa simpan setahun. Tepung jagung yang memiliki kadar air rendah $(7,4-9,27 \%)$ ini diharapkan memiliki umur simpan lebih dari setahun sehingga penggunaan dan distribusinya lebih luas.

\section{Berat Kering}

Fermentasi dengan inokulum Saccharomyces cerevisiae dan Rhizopus oligosporus menunjukkan perbedaan yang tidak nyata $(\mathrm{P}>0,05)$ terhadap kandungan bahan kering, meskipun secara nominal menunjukkan adanya penurunan. Adanya penurunan kandungan bahan kering saat fermentasi, diduga disebabkan adanya perombakan bahan kering substrat dimana bahan organik mengalami penguraian oleh mikroorganisme yang terdapat pada inokulum Saccharomyces cerevisiae dan Rhizopus oligosporus.

Selama proses fermentasi akan terjadi peningkatan kadar air dalam substrat karena penguraian bahan kering total, yang akan digunakan sebagai sumber energi atau bahan pembentuk sel baru sehingga kandungan bahan keringnya akan menurun. Kandungan bahan kering pada perlakuan FS0,5, FS0,75, FR0,5 dan FR0,75 yang cenderung lebih rendah dibandingkan dengan F0, memberikan indikasi bahwa perlakuan yang mempunyai bahan kering rendah akan mempunyai kandungan air yang lebih tinggi. Tepung biji durian merupakan media sumber karbon yang dapat digunakan sebagai media oleh Saccharomyces cerevisiae untuk tumbuh selama proses fermentasi dengan demikian maka diperoleh bahan kering yang paling rendah pada penggunaan Saccharomyces cerevisiae tertinggi.

\section{Protein Kasar (PK)}

Salah satu variabel yang diukur pada penelitian ini yaitu protein kasar yang merupakan nutrisi yang sangat penting dalam menilai kualitas suatu bahan pakan. Protein merupakan bagian yang terpenting dalam sel hidup, baik hewan maupun 
tumbuhan. Protein berperan utama dalam kehidupan oleh karena mempunyai hubungan yang erat dengan semua aspek biologik dalam tubuh makhluk hidup melalui proses fisika dan kimia (Irianto, 2013).

Pengaruh fermentasi dengan menggunakan inokulum Saccharomyces cerevisiae dan Rhizopus oligosporus memberikan perbedaan yang tidak nyata $(\mathrm{P}$ $>0,05)$ terhadap kandungan protein kasar (Tabel 1). Secara nominal menunjukkan adanya peningkatan. Hal ini menunjukkan bahwa penggunaan inokulum Saccharomyces cerevisiae dapat meningkatkan kandungan protein kasar sebagaimana yang terlihat pada perlakuan P1 yang mempunyai kandungan Protein kasar tertinggi $(6,95 \%)$.

Peningkatan kandungan protein kasar tersebut diduga disebabkan oleh pada waktu inkubasi ragi tape Saccharomyces cerevisiae tumbuh dan berkembang sehingga akan meningkatkan massa mikrobial yang kaya protein. Peningkatan jumlah sel-sel mikrobial secara signifikan juga akan meningkatkan kandungan protein substrat tepung limbah biji durian karena protein kasar berasal dari protein mikroorganisme.

Menurut Winarno (2010) fermentasi merupakan suatu proses perubahan substrat baik secara fisik atau kimiawi pada konsisi aerob maupun anaerob oleh aktivitas enzim yang dihasilkan oleh mikroba dengan tujuan meningkatkan nilai nutrisi tekstur dan palatabilitas serta pereduksian faktor antinutrisi.

\section{Serat Kasar}

Pengaruh fermentasi dengan Saccharomyces cerevisiae dan Rhizopus oligosporus terhadap kandungan Serat kasar tepung biji durian menunjukkan perbedaan yang tidak nyata.

Analisis sidik ragam menunjukkan hasil untuk serat kasar tepung biji durian fermentasi pada masing-masing perlakuan adalah sebagai berikut : F0 (2,60\%), FS0,5 (2,68\%); FS0,75 (1,27\%); FR0,5 (2,96\%);
FR0,75 (3,26\%). cenderung terjadi Penurunan kandungan serat kasar pada perlakuan fermentasi dengan hasil serat kasar terendah pada perlakuan FS0,75, terjadi penurunan kandungan serat kasar disebabkan oleh fermentasi menggunakan Saccharomyces cerevisiae dan Rhizopus oligosporus dapat memecah ikatan-ikatan serat yang komplek menjadi sederhana.

Menurut Sarwono (2010) makanan yang telah mengalami fermentasi mempunyai kadar gizi lebih tinggi dibanding dengan bahan asal. Hal tersebut disebabkan oleh adanya kerja enzim yang dihasilkan oleh mikroba sendiri dan enzim tersebut bersifat katabolik atau memecah senyawa-senyawa yang kompleks menjadi sederhana sehingga mudah dicerna.

\section{Lemak Kasar}

Hasil analisis ragam terhadap kandungan lemak kasar (Tabel 1) menunjukkan bahwa fermentasi dengan menggunakan inokulum Saccharomyces cerevisiae dan Rhizopus oligosporus memberikan perbedaan yang tidak nyata ( $\mathrm{P}$ $>0,05)$.

Penurunan pada kandungan lemak kasar tepung limbah biji durian hasil fermentasi, Penurunan kandungan lemak pada perlakuan ini disebabkan oleh aktivitas enzim lipase yang dihasilkan oleh khamir; untuk merombak kandungan lemak substrat sebagai sumber energi bagi pertumbuhannya. Khamir akan menyerang lemak dan protein setelah menyerang karbohidrat sebagai sumber energinya (Chopra dan Khuller, 1987).

Saccharomyces cerevisiae mampu mendegradasi lemak kasar yang ditunjukkan dengan rendahnya kandungan lemak kasar pada perlakuan fermenasi karena digunakan untuk memenuhi kebutuhan energi sebagai pertumbuhan khamir. Umiyasih (2008) menyatakan bahwa kadar karbohidrat dan aktivitas ragi Saccharomyces cerevisiae juga turut berpengaruh terhadap kadar lemak. (Ardhana, 1982) juga menyatakan penguraian lemak oleh khamir disebabkan 
aktivitas enzim lipase yang bekerja dalam pemecahan lemak dari substrat sehingga kandungan bahan organik selama fermentasi mengalami penurunan. Kemampuan mikroba memecah trigliserida disebabkan karena adanya enzim lipase (1-3). Jenis enzim lipase $1-3$ dapat melepaskan ikatan asam lemak dengan gliserol, Rhizopus oligosporus (jamur pada tempe) merupakan salah satu jamur yang mampu menghasilkan lipase 1-3.

\section{Abu}

Berdasarkan hasil analisis sidik ragam diketahui bahwa dari perlakuan yang di analisa, tepung limbah biji durian yang difermentasi memiliki kadar abu yang berbeda tidak nyata dengan kadar abu tepung biji durian kontrol,

Kecendrungan persentase abu tertinggi terdapat pada perlakuan FS0,5 yang difermentasi dengan $0,5 \%$ ragi tape, ini kemungkinan disebabkan oleh banyaknya kandungan mineral yang ada pada tepung biji durian, mengingat tepung tepung biji durian diolah dengan proses fermentasi dimana saat fermentasi akan terjadi perubahan fisik dan kimiawi tepung biji durian.

Kadar abu digunakan untuk menunjukkan kelayakan proses pengolahan suatu bahan. Dari Tabel 1 dapat dilihat bahwa konsentrasi ragi memberikan pengaruh terhadap kadar abu tepung biji durian fermentasi. Makin tinggi level ragi cendrung meningkatkan kadar abu tepung biji durian fermentasi. Hal ini sesuai dengan pernyataan Astawan (2008) bahwa ragi dapat menghasilkan enzim fitase yang dapat menguraikan asam fitat (yang mengikat beberapa mineral) menjadi fosfor dan inositol. Dengan terurainya asam fitat, maka mineral-mineral tertentu (magnesium, besi, kalsium, dan seng) menjadi lebih tersedia. Semakin tinggi konsentrasi ragi yang diberikan, maka kadar abu akan semakin tinggi.

\section{Asam Amino}

Protein dalam bahan pakan yang dikonsumsi oleh hewan akan diserap oleh usus dalam bentuk asam amino. Mutu protein suatu bahan makanan ditentukan ketersediaan asam amino yang dapat diserap oleh tubuh. Suprijatna et al. (2005) menyatakan bahwa meskipun protein pakan sesuai kebutuhan, tetapi defisiensi asam amino esensial berdampak pada efisiensi penggunaan protein untuk pembentukan jaringan tubuh atau produksi telur menurun. Beberapa asam amino yang merupakan peptida dan molekul-molekul protein kecil juga dapat diserap melalui dinding usus, kemudian masuk ke dalam pembuluh darah (Winarno, 1992). Susunan asam amino pada tepung limbah biji durian dapat dilihat pada Tabel 2.

Tabel 2. Rataan kandungan asam amino tepung biji durian dengan perlakuan yang berbeda

\begin{tabular}{|c|c|c|c|c|c|c|}
\hline \multirow[t]{2}{*}{ Variabel } & F0 & FS0,5 & FS0,75 & FR0,5 & FR0,75 & Notasi \\
\hline & \multicolumn{6}{|c|}{$\%$} \\
\hline Asam Aspartat & $0,87 \pm 0,030$ & $0,74 \pm 0,06$ & $0,81 \pm 0,10$ & $0,76 \pm 0,05$ & $0,72 \pm 0,07$ & ns \\
\hline Asam Glutamin & $0,96 \pm 0,05$ & $0,80 \pm 0,04$ & $0,88 \pm 0,07$ & $0,88 \pm 0,08$ & $0,85 \pm 0,13$ & ns \\
\hline Serin & $0,33 \pm 0,01$ & $0,30 \pm 0,01$ & $0,33 \pm 0,02$ & $0,33 \pm 0,03$ & $0,32 \pm 0,05$ & ns \\
\hline Histidin & $0,13 \pm 0,01$ & $0,10 \pm 0,01$ & $0,11 \pm 0,02$ & $0,13 \pm 0,02$ & $0,12 \pm 0,02$ & ns \\
\hline Glisin & $0,33 \pm 0,01$ & $0,28 \pm 0,02$ & $0,32 \pm 0,02$ & $0,31 \pm 0,02$ & $0,32 \pm 0,08$ & ns \\
\hline Treonin & $0,31 \pm 0,03$ & $0,29 \pm 0,02$ & $0,33 \pm 0,04$ & $0,35 \pm 0,05$ & $0,31 \pm 0,06$ & ns \\
\hline Arginin & $0,42 \pm 0,03$ & $0,36 \pm 0,03$ & $0,37 \pm 0,03$ & $0,36 \pm 0,13$ & $0,38 \pm 0,06$ & ns \\
\hline Alanin & $0,33 \pm 0,01$ & $0,29 \pm 0,01$ & $0,32 \pm 0,02$ & $0,32 \pm 0,03$ & $0,25 \pm 0,11$ & ns \\
\hline Tirosin & $0,34 \pm 0,14^{\mathrm{a}}$ & $0,23 \pm 0,04^{\mathrm{a}}$ & $0,24 \pm 0,05^{\mathrm{ab}}$ & $0,22 \pm 0,02^{\mathrm{ab}}$ & $0,15 \pm 0,07^{\mathrm{b}}$ & $*$ \\
\hline Metionin & $0,07 \pm 0,01$ & $0,07 \pm 0,01$ & $0,06 \pm 0,02$ & $0,07 \pm 0,02$ & $0,17 \pm 0,28$ & ns \\
\hline Valin & $0,40 \pm 0,01$ & $0,37 \pm 0,02$ & $0,39 \pm 0,02$ & $0,39 \pm 0,03$ & $0,31 \pm 0,11$ & ns \\
\hline Penilalanin & $0,35 \pm 0,01$ & $0,31 \pm 0,02$ & $0,33 \pm 0,02$ & $0,32 \pm 0,03$ & $0,26 \pm 0,09$ & ns \\
\hline Isoleusin & $0,34 \pm 0,01$ & $0,33 \pm 0,02$ & $0,35 \pm 0,03$ & $0,28 \pm 0,17$ & $0,36 \pm 0,07$ & ns \\
\hline Leusin & $0,52 \pm 0,01$ & $0,47 \pm 0,02$ & $0,51 \pm 0,02$ & $0,52 \pm 0,03$ & $0,39 \pm 0,17$ & ns \\
\hline Lisin & $0,36 \pm 0,03$ & $0,29 \pm 0,05$ & $0,29 \pm 0,08$ & $0,23 \pm 0,11$ & $0,29 \pm 0,11$ & ns \\
\hline Asam Amino Total & $6,07 \pm 0,29^{a}$ & $5,20 \pm 0,21^{\mathrm{a}}$ & $5,60 \pm 0,32^{\mathrm{ab}}$ & $5,45 \pm 0,28^{\mathrm{ab}}$ & $5,18 \pm 0,71^{\mathrm{b}}$ & $*$ \\
\hline
\end{tabular}


Keterangan : F0 = Tepung Biji Durian Kukus ; FS = Fermentasi dengan 0,5 \% Saccharomyces cerevisiae $; \mathrm{FS}=\mathrm{Fermentasi}$ dengan 0,75 $\%$ Saccharomyces cerevisiae ; FR = Fermentasi dengan $0,5 \%$ Rhizopus oligosporus; FR = Fermentasi dengan $0,75 \%$ Rhizopus oligosporus. Superskrip yang diikuti dengan huruf kecil yang bebeda pada kolom yang sama menunjukkan perbedaan yang sangat nyata $(\mathrm{P}<0,05)$ antar perlakuan.

Berdasarkan data pada Tabel 2 menunjukkan bahwa paramater asam amino pada perlakuan tidak memberikan pengaruh yang nyata terhadap parameter Asparatic_Acid, Glutamic_Acid, Serine, Histidine, Glycine, Threonine, Arginine, Alanine, Methionine, Valine, Phenylalanine, I_leucine, Leucine, Lysine menunjukkan hasil yang non signifikan, sedangkan pada parameter tyrosine yang kemudian diikuti oleh total asam amino yang memperoleh hasil yang signifikan $(\mathrm{P}<0,05)$. Kualitas protein suatu bahan ditunjukkan dengan skor kimia asam-asam amino merupakan suatu metode untuk menduga kualitas protein oleh asam-asam amino yang relatif paling kekurangan yang dibandingkan dengan profil asam amino dari protein standar (Block \& Mitchell 1978).

Keseimbangan asam amino esensial tidak saja ditentukan oleh kandungan asam amino esensial total dari bahan pakan, tetapi juga ditentukan oleh keseimbangan asam amino esensial yang tersusun di dalam protein tersebut.

Proses fermentasi tepung limbah biji durian pada penelitian ini rata-rata memperoleh hasil yang tidak signifikan bahkan cendrung menurunkan angka asam amino bila dibandingkan dengan asam amino tepung limbah biji durian kontrol yang tidak difermentasi. Menurunnya kandungan asam amino kemungkinan disebabkan oleh deaminasi. Proses deaminasi adalah proses pemecahan (hidrolisis) asam amino menjadi asam keto dan ammonia $\left(\mathrm{NH}_{4}{ }^{+}\right)$. Salah satu hasil deaminasi ini adalah senyawa nitrogen $(\mathrm{C}$, $\mathrm{H}$ dan $\mathrm{O}$ ) yang digunakan sebagai sumber energi untuk pertumbuhan mikroba.

Beberapa asam amino harus tersedia dalam ransum dengan jumlah yang cukup karena merupakan asam amino esensial salah satu nya yaitu metinonin. Menurut Wahju (1997), bungkil kedelai meskipun mengandung protein tinggi akan tetapi defisien akan asam amino metionin. Hasil fermentasi pada penelitian ini menunjukkan terjadi peningkatan kandungan asam amino biji durian yang difermentasi dengan Rhizopus oligosporus $0,75 \%$.

\section{KESIMPULAN}

Berdasarkan hasil penelitian yang diperoleh dapat disimpulkan bahwa perlakuan fermentasi tepung limbah biji durian dengan ragi tape (Saccharomyces cerevisiae) dan ragi tempe (Rhizopus oligosporus) tidak meningkatkan kandungan asam amino dan nutrisi hanya terjadi penurunan pada nilai serat kasar dan peningkatan kadar air. Hasil terbaik yang menunjukkan perubahan nilai nutrisi yaitu pada perlakuan dengan menggunakan ragi tape $0,75 \%$ mengacu pada kemampuan menguraikan serat kasar.

\section{DAFTAR PUSTAKA}

Ariffin, A.A, H.M.P. Ghazali Kavousi. 2014. Validation of a HPLC method for determination of hydroxymethylfurfural in Crude Palm Oil, Journal of Food Chemistry $154: 102-107$.

Ardhana, M. 1982. The Microbial Ecology og Tape Ketan Fermentation. Thesis. The University of New South Wales University, Sydney.Buckle, K.A., R.A. Edwards., G.H. Fleet and M. Wootton, 1987. Ilmu Pangan. Terjemahan H. Purnomodan Adiono. UI - Press, Jakarta.

Block RJ, Mitchell HH. 1978. Some relationship between the amino acid contents of proteins and their nutritive values for the rat. Nutrition Reviews. 36(9): 281-283. http://doi.org/dwx2v5

[BPS] Badan Pusat Statistik. 2013. Produksi Buah-buahan dan 
Tanaman Pangan Propinsi Bengkulu Tahun 2010.

Chopra, A. and G.K. Khuller. 1987. Lipid metabolism of fungi. Crit. Rev. Microbiol. 11: 209

Ciptadi, W. dan Z, Nasution 1980. Pengolahan Ubi Ketela Pohon. Departemen Teknologi Pengolahan Hasil Pertanian. Fatameta. IPB Bogor, Bogor.

Irianto, K.2013. Gizi Seimbang Dalam Kesehatan Reproduksi. Penerbit Alfabet. Bandung.

Richana, N., Budiyanto, A. dan Mulyawati, I. 2010. Pembuatan Tepung Jagung Termodifikasi dan Pemanfaatannya untuk Roti. Prosiding Pekan Serealia Nasional.

Rita, W., Sunaryadi, dan L. Malianti. 2014. Pemanfaatan Tepung Biji durian (Durio zibethinus Murr) dan Suplementasi Mineral Proteinat dalam Ransum terhadap Peforman Ayam Broiler. Laporan Penelitian Hibah Bersaing Universitas Muhammadiyah Bengkulu.

Sarwono. 2010. Usaha Membuat Tempe Dan Oncom. Jakarta. Penebar Swadaya.

Sasongko, P.2009. Detoksifikasi Umbi Gadung (Dioscorea Hispida Dennst.) Proses Fermentasi Menggunakan Kapang Mucor racemosus, Jurnal Teknologi Pertanian, 10(3), hal. 205-215.

Steel, R.G.D. and J.H. Torrie. 1991. Principles and Procedures of Statistics. McGraw Hill Co. Inc. New York

Sulistyowati, E., A. Sudarman , K. G. Wiryawan and T. Toharmat. 2015. The Nutritive Values of PUFAConcentrate Supplemented with Yeast and Curcuma Xanthorrhiza Roxb Stored In several Weeks. J. Indonesian Trop. Anim. Agric. 40 (1) : 11-22.

Umiyasih, U., and Y.N. Anggraeny. 2008. Pengaruh fermentasi saccharomyces cerevisiae terhadap kandungan nutrisi dan kecernaan ampas pati aren (arenga pinnata merr.). Seminar Nasional Teknologi Peternakan dan Veteriner

Wahju, J. 1997. Ilmu Nutrisi Unggas. Cetakan Keempat. Gadjah Mada University. Press. Yogyakarta.

Winarno, F. G. 1992. Pangan Gizi, Teknologi dan Konsumen. Gramedia Pustaka Utama. Jakarta.

Winarno, F.G. 2004. Kimia Pangan Dan Gizi. Gramedia Pustaka Utama. Jakarta. 